\title{
The diffusion and adoption of public sector innovations: A meta- synthesis of the literature
}

Hanna de Vries ${ }^{1}$, Lars Tummers ${ }^{2}$, Victor Bekkers ${ }^{3}$

Accepted version for Perspectives on Public Management and Governance

Address correspondence to the author at Devries@essb.eur.nl

To be cited as: De Vries, H.A., Tummers, L.G., and Bekkers, V.J.J.M. (2018). The diffusion and adoption of public sector innovations: A meta-synthesis of the literature. Perspectives on Public Management and Governance

1 Department of Public Administration and Sociology, Erasmus University Rotterdam, Rotterdam, The Netherlands

${ }^{2}$ School of Governance, Utrecht University, Utrecht, The Netherlands

${ }^{3}$ Department of Public Administration and Sociology, Erasmus University Rotterdam, Rotterdam, The Netherlands 


\begin{abstract}
This article synthesizes the extensive literature on the diffusion and adoption of public sector innovations. Although various subfields within public administration have studied diffusion and adoption, these have tended to develop relatively independently. Hence, the lessons learnt in one area might not be evident elsewhere. We have therefore conducted a meta-synthesis of the literature and connected research in three subfields: public management, public policy, and e-government. We show that there is indeed little overlap between the fields with each relying on their own models and paradigms. Furthermore, they often fail to define the concepts of diffusion and adoption. In terms of antecedents, public management and public policy scholars mainly focus on the macro-institutional environment, whereas e-government scholars show a greater interest in the individual level. Based on our meta-synthesis, we develop an integrated list of important antecedents of public sector innovation diffusion and adoption. We also propose three lines for future research: (1) combine macro-, meso-, and micro-level approaches to develop a more nuanced and context-dependent understanding of diffusion and adoption; (2) clearly distinguish between innovation generation, innovation diffusion, and innovation adoption; and (3) draw more extensively on open innovation and collaborative innovation concepts given the crucial role of end-users in innovation diffusion and adoption.
\end{abstract}




\section{Introduction}

Public organizations around the world are facing unprecedented challenges to their legitimacy. These challenges address issues such as ageing populations, unemployment, climate change, and the revitalization of urban areas. At the same time, these organizations are wrestling with shrinking budgets, in part due to recent economic crises. Given their complexity, these challenges cannot be solved by relying on standard approaches (Hartley et al., 2013, Sørensen \& Torfing, 2011; Walker, 2014) and, as a result, public organizations are increasingly urged to innovate: to develop and adopt new practices that amount to a discontinuity with the past (De Vries et al., 2016; Osborne \& Brown, 2011).

When addressing the question of how innovations can be successfully implemented in public organizations, a crucial distinction that is often made in the innovation literature relates to the two stages of the innovation process. Here, the development of new ideas and practices, that constitute a transformative discontinuity with the past, is distinguished from the diffusion and adoption of such practices that have been developed elsewhere (Damanpour, 1991; Gopalakrishnan \& Damanpour, 1997; Rogers, 2003).

The crucial role that especially the latter stage, diffusion and adoption, can play in modernizing the public sector has been labelled the "public sector secret weapon" (Hartley, 2016, p. 95) because, in this way, public organizations can copy and adopt successes from elsewhere. The willingness and ability to adopt such practices, and integrate them into the organization, tells us something about the change capacity of public organizations. In other words, it is not only important that innovative practices are generated but, perhaps even more so, that these are then spread to and implemented in other settings.

In studying this topic, we draw on the definitions outlined by Rogers. Rogers (2003, p. 5) defines diffusion as "the process in which an innovation is communicated through certain channels over time among the members of a social system". Adopting an innovation is "the process through which an individual (or other decision-making unit) passes from first 
knowledge of an innovation, to the formation of an attitude toward the innovation, to a decision to adopt or reject, to implementation and use of the new idea, and to confirmation of this decision” (Rogers 2003, p. 20).

Although the diffusion and adoption issue is widely acknowledged by researchers (e.g., Berry \& Berry, 1990; Gray, 1973; Geenhalgh et al., 2004; Hartley 2016; Moore \& Benbasat, 1991, Shipan \& Volden, 2012; Taylor \& Todd, 1995; Tornatzky \& Klein, 1992, Walker, 2014; Zaltman, Duncan, \& Holbek, 1973, Zhang, Xu, \& Xiao, 2014), a shortcoming is that, while this topic is addressed in various public administration subfields, the scholars involved have their own discussions, approaches, and conceptualizations (e.g., Berry \& Berry, 2014; Greenhalgh et al., 2004; Hartley, 2016). Hence, although the distinct subfields each possess extensive and valuable knowledge on this topic, the lessons learnt in one area might not be picked up elsewhere.

To address this issue, this article explores whether the findings from various, but related, subfields can be integrated, with the overall aim to see how they can learn from each other. In doing so, we aim to establish a common knowledge reservoir that can be used to develop a more comprehensive and integrated theoretical and empirical understanding. We synthesize research findings from the three main subfields that can be distinguished within the literature on this topic: public management, public policy, and e-government. These fields are currently treated as distinct, due to their foci on different innovation types, but are closely related: in essence, they all describe the same process, namely innovation diffusion and adoption. A more extensive discussion on the selection of these subfields and their distinct conceptualizations and approaches is presented in section 2. Although there have been a number of overviews, mainly addressing public innovation generating processes (e.g., De Vries et al., 2016; Osborne \& Brown, 2011), there has been no overarching study addressing the topic of diffusion and adoption. 
To help explore this large and heterogeneous literature, we have conducted a metasynthesis of the literature. Here, we go beyond a systematic review, an approach that has become increasingly popular in public administration studies, by reviewing other systematic reviews and literature reviews. We have explicitly opted for such a meta-synthesis because this is seen as the most rigorous way of integrating knowledge from different fields, and such reviews have "great potential for providing 'big picture' summaries of empirical research" (see Cooper \& Koenka, 2012, p. 459). Based on the above discussion, this article aims to answer the following main research question: To what extent are the subfields (public management, public policy, and e-government) that study the diffusion and adoption of public sector innovations integrated, and how can they learn from each other?

In order to establish the broader picture, we first identified the relevant seminal papers and books, thereby answering our first research question (RQ1): What are the most cited publications in the three scholarly subfields related to public sector innovation diffusion and adoption? Answering this question enables us to identify the publications that are the most often cited, and also to see whether the distinct subfields use the same studies. Moreover, such insights might also show which publications might be the most promising to include in future research, for instance because they are often cited.

Following this question, aiming to provide some general insights regarding the most cited publications, we analyse the dominant theories, theoretical models, and reform paradigms within the various scholarly subfields. This will help in developing a more comprehensive and integrated theoretical understanding. This is formulated as the following research question (RQ2): What theories, theoretical models, and reform paradigms are used in the three subfields? Answering this research question will enable us to see whether the fields' theoretical approaches and assumptions overlap and how they can build on each other's insights.

Third, given that our aim is to develop, alongside a more integrated theoretical understanding, a more integrated empirical understanding of this topic (i.e., increased insight 
into the relevant drivers and barriers highlighted in the distinct subfields), we identify the main empirical antecedents that are seen as influencing innovation diffusion and adoption. This is reflected in our final research question (RQ3): Which antecedents influence the diffusion and adoption process of public sector innovations, and what are the similarities and differences in focus across the three subfields?

\section{Key Research Areas Relevant to Public Sector Innovation Diffusion and}

\section{Adoption}

In table 1, we list the three research areas (public management, public policy, and egovernment) that provide evidence relevant to the diffusion and adoption of public sector innovations. In this table, we highlight the similarities and differences in terms of these topics as conceptualized in the distinct literature streams.

Table 1. Key Research Areas Relevant to Public Sector Innovation Diffusion and Adoption

\begin{tabular}{|l|l|l|l|l|}
\hline $\begin{array}{l}\text { Subfield of } \\
\text { analysis }\end{array}$ & $\begin{array}{l}\text { Main innovation } \\
\text { type addressed }\end{array}$ & Examples & $\begin{array}{l}\text { Background and } \\
\text { rationale for } \\
\text { studying } \\
\text { innovation }\end{array}$ & $\begin{array}{l}\text { Conceptualization } \\
\text { of diffusion and } \\
\text { adoption }\end{array}$ \\
\hline $\begin{array}{l}\text { Public } \\
\text { management }\end{array}$ & $\begin{array}{l}\text { All innovation } \\
\text { types } \\
\text { namely } \\
\text { administrative/ } \\
\text { technological } \\
\text { process } \\
\text { innovation; } \\
\text { product/service } \\
\text { innovation; } \\
\text { governance } \\
\text { innovation; } \\
\text { conceptual } \\
\text { innovation) }\end{array}$ & $\begin{array}{l}\text { Management by } \\
\text { objectives; use of } \\
\text { benchmarking } \\
\text { websites; } \\
\text { outsourcing and } \\
\text { privatization in } \\
\text { provision of } \\
\text { public services; } \\
\text { use of new } \\
\text { paradigms such as } \\
\text { a private-sector } \\
\text { approach to the } \\
\text { provision of } \\
\text { public services }\end{array}$ & $\begin{array}{l}\text { Related to various } \\
\text { reform } \\
\text { movements in the } \\
\text { public sector, } \\
\text { including NPM } \\
\text { and NPG }\end{array}$ & $\begin{array}{l}\text { No generally } \\
\text { applied } \\
\text { conceptualization }\end{array}$ \\
\hline Public policy & $\begin{array}{l}\text { Mainly } \\
\text { governance } \\
\text { innovation and } \\
\text { conceptual } \\
\text { innovation }\end{array}$ & $\begin{array}{l}\text { Formation of } \\
\text { governance } \\
\text { networks; } \\
\text { paradigm shifts } \\
\text { such as the } \\
\text { transition from } \\
\text { welfare to }\end{array}$ & $\begin{array}{l}\text { Originated in the } \\
\text { attention given to } \\
\text { innovation by } \\
\text { state governments, } \\
\text { which could also } \\
\text { be linked to the } \\
\text { presence of }\end{array}$ & $\begin{array}{l}\text { Often drawing on } \\
\text { Rogers' notions of } \\
\text { diffusion. Scholars } \\
\text { have also } \\
\text { identified a variety } \\
\text { of other alternative } \\
\text { mechanisms, such }\end{array}$ \\
\hline
\end{tabular}




\begin{tabular}{|l|l|l|l|l|}
\hline & workfare & $\begin{array}{l}\text { various societal } \\
\text { problems }\end{array}$ & $\begin{array}{l}\text { as learning, } \\
\text { imitation, } \\
\text { normative } \\
\text { pressure, } \\
\text { competition, and } \\
\text { coercion }\end{array}$ \\
\hline E-government & $\begin{array}{l}\text { Mainly } \\
\text { technological } \\
\text { process innovation } \\
\text { and } \\
\text { product/service } \\
\text { innovation }\end{array}$ & $\begin{array}{l}\text { Digital assessment } \\
\text { of taxes; use of } \\
\text { text messaging } \\
\text { devices }\end{array}$ & $\begin{array}{l}\text { Driven by } \\
\text { technological } \\
\text { developments. } \\
\text { Modern ICTs, } \\
\text { especially Internet } \\
\text { and } \\
\text { technologies, are } \\
\text { seen as enhancing } \\
\text { the access, } \\
\text { transparency, } \\
\text { efficiency, and } \\
\text { quality of public } \\
\text { processes and } \\
\text { services }\end{array}$ & $\begin{array}{l}\text { Mainly described } \\
\text { in terms of } \\
\text { individual } \\
\text { acceptance, } \\
\text { including aspects } \\
\text { such as attitude } \\
\text { towards an } \\
\text { innovation and } \\
\text { intention to use, } \\
\text { while Rogers, } \\
\text { conceptualizations } \\
\text { are also applied }\end{array}$ \\
& & & \\
\hline
\end{tabular}

An initial general remark related to table 1 concerns the selection of these subfields. The rationale to include these three subfields is linked to the innovation type emphasized in each field. The definition of innovation in the public sector is often quite broad, and one common approach in studying public sector innovation is to distinguish between various types of innovation. Although studies have varied in the specific innovation types they define as important, commonly used categories include: 1) process innovations, which can be either administrative (the creation of new organizational forms, the introduction of new management methods, and new working methods), or technological in nature (creation or use of new technologies, introduced in an organization to provide services to users and citizens); 2) product or service innovations (creation of new public services or products); 3 ) governance innovations (development of new forms and processes to address specific societal problems); and 4) conceptual innovations (introduction of new concepts, frames of reference, or paradigms that help to reframe the nature of specific problems as well as their possible solutions) (De Vries, Bekkers, \& Tummers, 2016; for related categorizations see also Bekkers et al., 2011,; Torfing, 2016; Walker, 2014). 
As a result, scholars in different public administration subfields vary in the innovation types they focus on. For instance, public management scholars often address new processes, such as the application of new management methods in public organizations, while the use of new technologies, such as the provision of online services for citizens, is frequently addressed in the e-government literature.

Nevertheless, although these distinct fields vary in what they study (see table 1, and summarized below), in essence they all study the same process (namely, innovation diffusion and adoption). This consensus in the process studied makes it particularly relevant to see how these distinct fields can be integrated and learn from each other.

1. Public management: public management studies (e.g., Borins, 2014; Walker, 2014) have addressed a broad range of innovations involving all innovation types. This attention to innovation can be related to various reform movements in the public sector. For instance, New Public Management (NPM; Hood 1991; Osborne and Gaebler 1992), through its focus on business and managerial practices, often emphasizes process innovation. More recently, based on New Public Governance ideas (NPG; Osborne, 2006) associated with networked or collaborative governance (Torfing, 2016), many public innovations involve both internal and external stakeholders. The latter ideas typically assume that governance networks bring together relevant and affected actors with different ideas, skills, and resources (i.e., governance innovation) (Torfing, 2016). More broadly, such paradigm shifts also include a conceptual change (i.e., conceptual innovation) within the public sector as traditional assumptions are fundamentally altered. 
2. Public policy: public policy scholars have addressed a broad variety of policy innovations which can be characterized as both governance (e.g., involvement of different partners such as through professional networks) and conceptual (e.g., new policies aiming at a transition from welfare to workfare) in nature.

3. E-government: here, the attention to innovation can be related to the substantial role that information and communication technologies (ICT) play as they become intertwined with the formulation, implementation, and evaluation of public processes and the delivery of public services (Bekkers, 2007; Gil-García, Dawes, \& Pardo, 2017; Meijer, 2015). The term e-government broadly refers to the use of ICT to facilitate the daily administration of government, such as much of the work of local governments, but can also include technology applications in other public settings such as public healthcare (e.g., Greenhalgh et al., 2004).

By explicitly including the e-government perspective, our study responds to the calls advocated by various authors to connect the public management and the e-government literatures (e.g., Gil- García et al., 2017; Taylor \& Lips, 2008). In this regard, Gil-Garcia et al. (2017) express surprise that the e-government literature has been largely ignored by public management scholars. Here the argument is that ICT have become ubiquitous in the public sector in recent years and it is difficult to think of a public problem or government service that does not involve ICT in some substantial way (i.e., many innovations, such as online services for citizens, are driven by technology). This extensive use of technologies, in both the implementation process and services, make them an essential component in the innovation process. This view that ICT is inherently connected to innovation has been expressed by various other authors (for instance, Meijer 2015). Here, Taylor and Lips' (2008) work is also crucial in urging connection of the egovernment field with the broader public administration literature as, according to these 
authors, e-government perspectives are inherently part of the world of public administration by addressing the informational relationships between governments and citizens.

Having justified the fields covered in our meta-synthesis, the next section describes the methodology applied in conducting the meta-synthesis.

\section{Meta-Synthesis Methodology}

\subsection{Search Strategy}

Four complementary search strategies were employed to identify potentially relevant reviews. First, electronic databases were searched for publications using conventional terms such as 'innovation', 'diffusion', and 'adoption', plus synonyms such as 'acceptance' as equivalent to adoption. Moreover, we also included the term 'e-government' and 'technology' because, in the e-government literature, the use of new technologies is often viewed as a driver for, or source of, public innovation (see Bekkers, 2007; Meijer, 2015). Moreover, 'policy diffusion', 'policy convergence' and 'policy transfer' were also included as search terms as these are commonly used in the public policy literature as equivalents to innovation diffusion (see Berry \& Berry, 2014; Knill, 2005). Finally, we included the search term 'reform' as equivalent to innovation. This led to the inclusion of the following keywords: [innovat*] or [technolog* innovat*] or [information technology] or [technology] or [e-government] or [electronic government] or [digital government] or [public policy] or [policy transfer] or [policy diffusion] or [policy convergence] or [reform] plus one of the following: [adopt*] or [accept*] or [copy*] or [convergence] or [diffusion] or [disseminat*] or [evaluat*] or [growth] or [implement*] or $\left[\mathrm{mimic}^{*}\right]$ or [prototyp*] or [replicat*] or [scal* up] or [transfer] or [upscal*] plus one of the following: [meta-analysis] or [review] or [systematic review] or [literature review] or [analysis]. These search combinations were used with the Web of Science and with Scopus. Each review article was then assessed for its eligibility based on its abstract and, in some cases, by reading the full text. 
Second, we also searched for articles published in top-ranked public administration, public policy, and e-government journals. The journals included were Governance, Government Information Quarterly, Information Polity, Journal of Public Administration Research and Theory, Journal of European Public Policy, Journal of Policy Analysis and Management, International Journal of Electronic Government Research (IJEGR), Policy Sciences, Policy Studies Journal, Public Administration, Public Administration Review, Public Management Review and Review of Policy Research.

Third, we looked for relevant chapters in books using Google Books and similar information sources.

Finally, after applying our inclusion criteria (discussed below) to our preliminary list of publications, we contacted experts in the field of public innovation and asked them if they knew of other publications that we should include.

A potential limitation of the search is that one of our main selection criteria was that the study should contain the word 'innovation', or commonly used synonyms, in its title or abstract. It is possible that there are relevant reviews dedicated to the topic that do not use these words in their abstract or title and, hence, would have been overlooked. We also chose not to include publications on related topics, such as 'change', because of the large increase in the number of records that would have resulted, although we accept that including other literature streams could have been valuable. Moreover, we acknowledge that by focusing on innovation types, rather than certain policy areas such as education or welfare, we might have overlooked some relevant innovation studies related to those specific fields as we did not include policy fields in our search criteria.

\subsection{Inclusion Criteria}


In our meta-synthesis, we adhere to the widely used PRISMA approach (Liberati et al., 2009).

Studies identified in our initial searches were included if they met all of the following inclusion criteria:

- Field: Reviews should deal with the adoption and diffusion of innovations in the public sector. The public sector was defined broadly as "those parts of the economy that are either in state ownership or under contract to the state, plus those parts that are regulated and/or subsidized in the public interest" (Flynn, 2007, p. 2).

- Study design: primarily, studies with a review character were included, such as literature reviews, meta-analyses, systematic reviews, and book chapters summarizing the state-of-the-art of innovation diffusion and adoption. We also included various studies that could be classified as more theoretical reviews or essays on the topic of innovation diffusion and adoption (e.g., Hartley et al., 2013; Shipan \& Volden, 2012) as these are often studies by leading scholars in the field and often provide an overview of the topic.

- Topic: When screening the review articles, the word innovation (or the abovementioned related terms) had to be included in the title and/or the abstract. However, the words adoption or diffusion (or the above-mentioned equivalents) did not have to be in the title or abstract given that reviews frequently address these topics without mentioning them in the introduction.

- Language: Only reviews in English were included.

- Publication status: Our initial intention was to include only international peer-reviewed journal articles and book chapters from well-established publishers. However, we did also include one other publication from the London Cabinet Office (Mulgan \& Albury, 2003) as this publication provided an overview of the topic of innovation diffusion and adoption. 
- Year of publication: We only included reviews published between January 1995 and August 2016 in order to have a manageable number of studies.

\subsection{Record Selection and Data Analysis}

The screening of all articles and books ultimately led to the inclusion of 73 review publications.

Our selection process is presented in figure 1. An overview of all the included studies in included in appendix A.

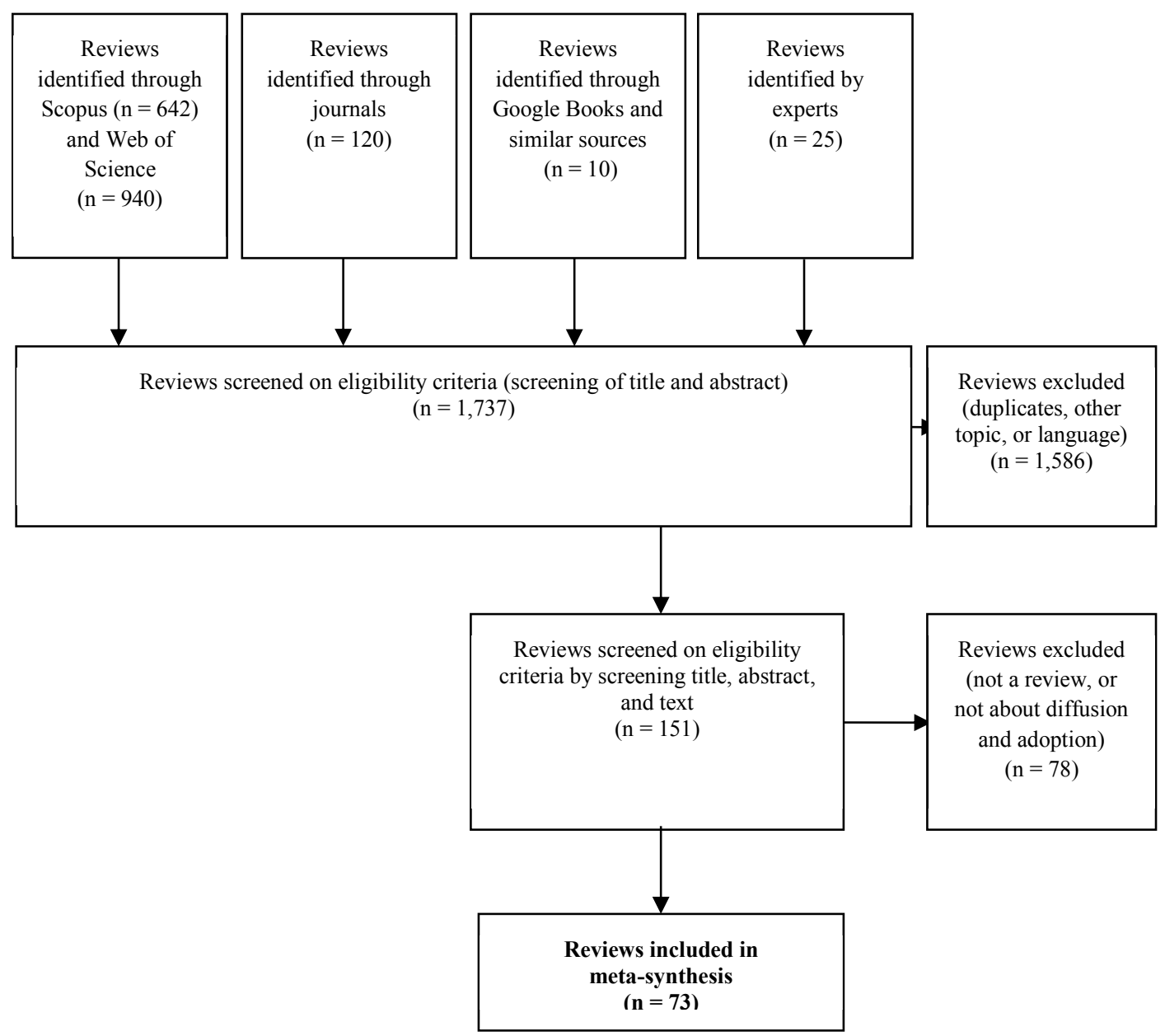

Figure 1. PRISMA Flow Diagram.

For each publication included, the following data were extracted: author(s); publication year; title; journal or publisher; type of study analysed; subfield of analysis (public management, 
public policy, or e-government); definitions used; topic addressed (diffusion, adoption, or both); theory, theoretical model, or reform paradigm applied; and the antecedents related to the diffusion and adoption process. In reading through the review publications, we especially sought text fragments where authors referred to antecedents that influenced diffusion and/or adoption. Comments on such antecedents were placed in an Excel database and coded. We then divided these findings into four broad categories reflecting four levels that are commonly considered when studying the innovation process (e.g., Cresswell \& Sheikh, 2013; Gagnon et al., 2012; Greenhalgh et al., 2004). These characteristics relate to: (1) the environmental or inter-organizational level (e.g., mimicking other organizations); (2) the organizational level (e.g., slack resources); (3) the individual level (e.g., employee autonomy); and (4) the innovation itself (e.g., the complexity of the innovation).

We recognize that such coding is inherently subjective, and that there are many links between the various types of antecedents. Nevertheless, we believe that the distinctions made can serve as a useful analytical tool to guide the extraction of important findings on innovation diffusion and adoption in the public sector. To safeguard quality, the researchers involved in this study discussed 'difficult' fragments in face-to-face meetings, by phone, or by Skype. During this process, new labels were introduced for some antecedents and others deleted.

\subsection{Review Method}

The method we adopted, namely a meta-synthesis, is perceived as having several advantages that outweigh potential disadvantages. A major advantage is that such overviews have a great potential to provide "big picture" summaries of empirical research. Moreover, they are particularly valuable for readers wanting to familiarize themselves with an area or looking for areas in which new research is needed (Cooper \& Koenka, 2012). Important limitations include the time lag involved. That is, some of the reviews included in a meta-synthesis may be several years old, and they will naturally be reviewing even older studies. As such, the most recent 
individual studies are very unlikely to feature in review studies covered in our analysis (Cooper \& Koenka, 2012).

\section{Defining Diffusion and Adoption}

In this section, we describe how diffusion and adoption are defined in the included reviews. Most notably, we found that the concepts of diffusion and adoption are often poorly defined in reviews, reflecting the lack of clear definitions for these activities.

As such, the first finding relates to the definitions used. We found that a majority of reviews $(70 \%)$ failed to provide a definition of what they consider to be diffusion or adoption. Definitions of diffusion, or synonyms such as transfer, were almost exclusively found in the public policy literature (see, for instance, Jordan \& Huitema, 2014; Knill, 2005), and often build on Rogers' (2003) definition. A definition of adoption was again only provided on a few occasions, described for instance as "the acceptance and incorporation of HIT [health information technologies] applications into everyday practice" (Cresswell \& Sheikh 2013, p. 74). Moreover, when we looked at the various types of adopter considered, we found that Mulgan and Albury (2003) were exceptional in that their study addressed the five types of adopters identified by Rogers (2003): innovators, early adopters, early majority, late majority, and laggards.

A related finding concerns the interchangeable use of the two terms. We found that most reviews were not clear as to whether they were addressing diffusion or adoption, or whether they separated the antecedents of the two processes. An illustrative example is the study by Cresswell and Sheikh (2013) who refer to both diffusion and adoption in their article, but subsequently state that, in essence, these both relate to the process through which innovations are introduced and then incorporated.

Thus, a preliminary overall conclusion is that the concepts of diffusion and adoption are poorly defined in the reviewed studies. As such, it seems that the concepts are taken for 
granted, or considered as a "black box". This, to an extent, explains the rather arbitrary use of the terms diffusion and adoption, and leads to a blurring of the two concepts.

\section{Analysis of Referencing Networks}

In this section, we analyse the referencing networks of the studies included in our metasynthesis. This will answer our first research question: What are the most cited publications in the three scholarly subfields related to public sector innovation diffusion and adoption? Here, our first aim was to see which publications are the most cited across all three disciplines (namely, public management, public policy, and e-government). Further, we also analysed whether the distinct subfields refer to the same publications. Examining this is important as, according to Lane, Koka, and Pathak (2006, p. 841), "one of the characteristics of a welldefined community of researchers is a network of citations among their papers that centers on a core set of papers delineating the constructs, theories, and methodologies shared by the community".

In order to capture the breadth of the field in the best possible way, we analysed not only the 55 studies in our dataset ${ }^{1}$, but also their reference lists. This provided 1,420 studies suitable for analysis. Figure 2 lists the articles and books that have been cited on at least 40 occasions.

\footnotetext{
${ }^{1}$ This network analysis is based on only the 55 studies included in the core collection of the Web of Science because the tool used (Sci2) could not be easily applied with other data formats.
} 


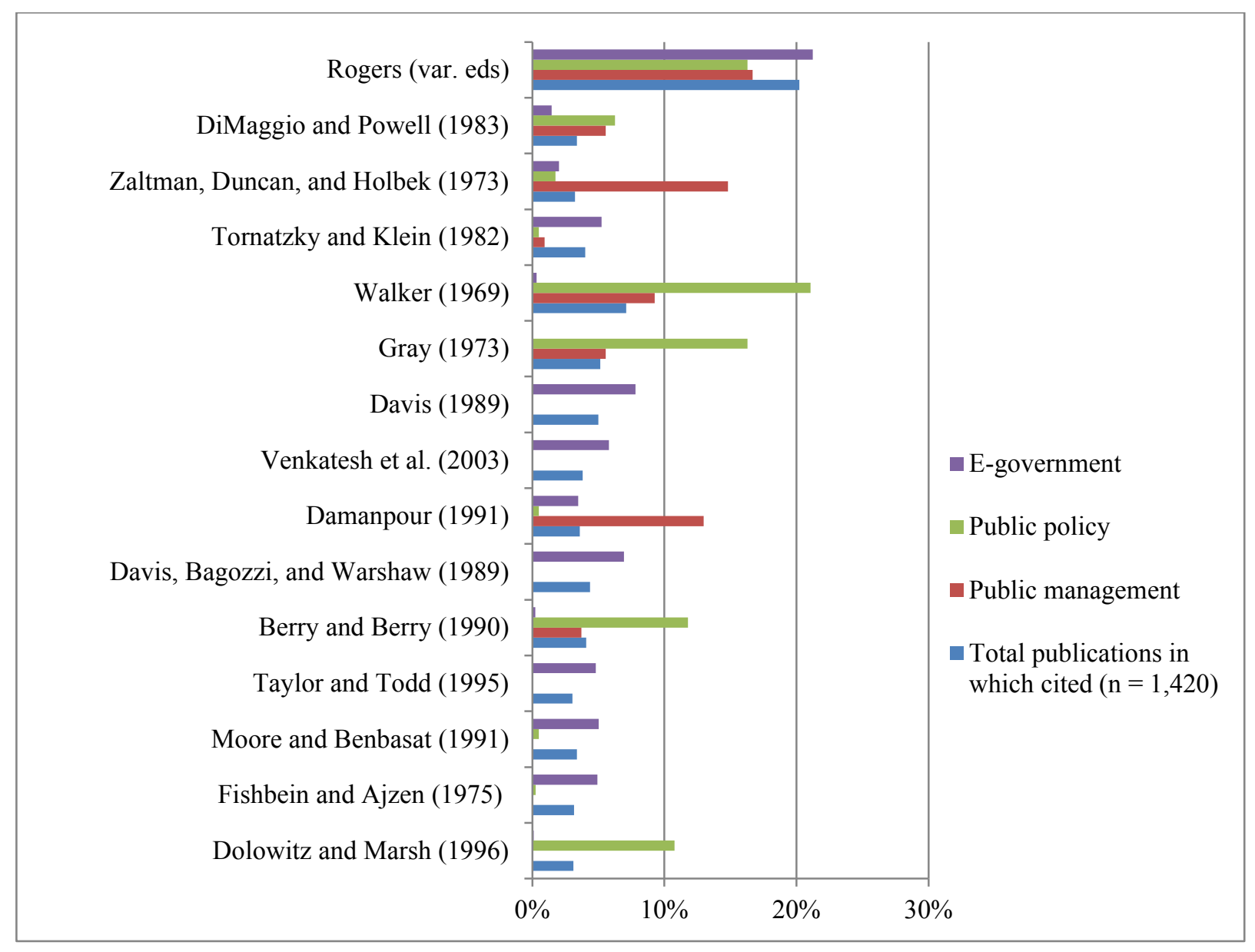

Figure 2. Results Network Analysis, Based on Studies Cited on 40+ Occasions.

From this figure, two main conclusions can be drawn. First, we found that studies from the different subfields rarely refer to the same core publications, with the notable exception of the diffusion of innovations study by Rogers (1983, 1995, and 2003 editions), which is frequently cited in all three bodies of knowledge analysed. Studies in all the fields analysed also refer to the well-known work on neo-institutionalism by DiMaggio and Powell (1983), albeit only on a few occasions. At the heart of neo-institutional theory is the argument that the pursuit of legitimacy leads organizations within a field to adopt a limited range of structures, strategies, and processes, and hence become isomorphic within that organizational field (DiMaggio and Powell 1983).

A second observation is that certain publications seem to be dominant and regularly referenced in one discipline but not appear at all in the others. For instance, important studies 
on technology acceptance, such as the studies by Davis (1989) and by Davis, Bagozzi, and Warshaw (1989), are almost exclusively cited in the e-government literature.

Summarizing, based on this analysis, we conclude that the various subfields of the public sector innovation field only all refer extensively to one work, namely Rogers' innovation theory (1983, 1995 or 2003 editions). Moreover, given that only a few core publications are used across the disciplines, there seems to have been very few attempts to gain insights from related subfields. This finding suggests that the distinct subfields can be considered as closed communities, a situation that can hamper cross-community learning. In the next section, we go on to describe the main theories, theoretical models, and reform paradigms used in each subfield in order to see how they could be integrated, and how the distinct disciplines could learn from one another.

\section{Theories, Theoretical Models, and Reform Paradigms}

This section provides an overview of the theories, theoretical models, and reform paradigms used to guide diffusion and adoption research (RQ2). As outlined earlier, although there is a distinction, most of the reviews showed a blurring of the two concepts and, therefore, in this meta-synthesis, diffusion and adoption have been treated as a single process. We view a theory as "a well-substantiated explanation of some aspect of the natural world that is acquired through the scientific method and repeatedly tested and confirmed through observation and experimentation" (American Association for the Advancement of Science 2016), a relevant example being the Unified Theory of Acceptance and Use of Technology (UTAUT) by Venkatesh et al. (2003). A reform paradigm can be defined as "a world view or a consistent pattern in that each contains particular conceptions and assumptions about the nature of the world, and the roles of politicians, managers and the population" (Hartley, 2005, p. 29), with NPM a relevant example (Hood, 1991; Osborne \& Gaebler, 1992). We also include theoretical models or frameworks, which we define as a perspective, or lens, through which a given topic 
is examined. The main results of this analysis are presented in table 2 and show that reviews of innovation diffusion and adoption refer to a diverse range of theories, including Rogers' (2003) on the diffusion of innovations and also technology acceptance models (e.g., Venkatesh et al., 2003). The public policy literature is characterized by models examining the influence of other nearby governments of actors with similar problems. Public management scholars mainly draw on reform paradigms, such as NPM, rather than referring to well-established theories.

Three main conclusions can be drawn. First, as in the earlier analysis, innovation diffusion theory, as formulated by Rogers (2003), is the most frequently mentioned theory across all three subfields. In his work, Rogers (2003) developed a theory of innovation diffusion that included four main elements that influenced the diffusion of a new idea: the innovation itself, communication channels, time, and the social system. The next most commonly featured overarching theory is the Technology Acceptance Model (TAM or TAM2) (Davis, 1989; Davis, Bagozzi, \& Warshaw 1989; Venkatesh \& Davis, 2000), or variants thereof such as UTAUT (Venkatesh et al., 2003) that combine various acceptance models. 
Table 2. Main Theories, Theoretical Models, and Reform Paradigms Stressed (Included on Two or More Occasions) in the Various Literature Streams

\begin{tabular}{|c|c|c|c|c|}
\hline & Short description & Key source & $\begin{array}{l}\text { Cited in the } \\
\text { following subfields }\end{array}$ & Applicability in other subfields \\
\hline \multicolumn{5}{|l|}{ Theories } \\
\hline Diffusion of innovations & $\begin{array}{l}\text { A theory that seeks to explain how, why, } \\
\text { and at what rate new ideas and technology } \\
\text { spread }\end{array}$ & Rogers (2003) & All subfields & Already applied in all subfields \\
\hline $\begin{array}{l}\text { Technology acceptance } \\
\text { models, such as TAM and } \\
\text { UTAUT, and related theories } \\
\text { such as the theory of reasoned } \\
\text { action (TRA) and the theory } \\
\text { of planned behaviour (TPB) }\end{array}$ & $\begin{array}{l}\text { Developed to study the acceptance of } \\
\text { technology by taking individuals into } \\
\text { account. TRA and TPB particularly aim to } \\
\text { explain the relationship between attitudes } \\
\text { and behaviours within human action }\end{array}$ & $\begin{array}{c}\text { Ajzen (1991); Davis } \\
\text { (1989); Fishbein and } \\
\text { Ajzen (1975); } \\
\text { Venkatesh and Davis } \\
\text { (2000); Venkatesh et } \\
\text { al. (2003) }\end{array}$ & E-government & $\begin{array}{l}\text { Could be applied in all subfields by } \\
\text { adjusting the object under analysis. For } \\
\text { instance, individual intention to use a } \\
\text { new technology could be replaced by } \\
\text { intention to use a certain policy or new } \\
\text { service }\end{array}$ \\
\hline Neo-institutionalism & $\begin{array}{l}\text { A theory which considers the processes by } \\
\text { which structures become established as } \\
\text { authoritative guidelines for social } \\
\text { behaviour (i.e., normative/ } \\
\text { coercive/mimetic pressures) }\end{array}$ & $\begin{array}{l}\text { DiMaggio and } \\
\text { Powell (1983) }\end{array}$ & $\begin{array}{l}\text { Mainly addressed in } \\
\text { the public } \\
\text { management and } \\
\text { public policy } \\
\text { literatures }\end{array}$ & $\begin{array}{c}\text { Could be applied in all subfields. } \\
\text { For instance, studies on e-government } \\
\text { could also take into account the impact } \\
\text { of mimetic pressures by peer } \\
\text { organizations }\end{array}$ \\
\hline Public choice & $\begin{array}{l}\text { A theory that studies self-interested agents } \\
\text { (voters, politicians, bureaucrats) and their } \\
\text { interactions }\end{array}$ & $\begin{array}{l}\text { Buchanan and } \\
\text { Tollison (1984) }\end{array}$ & Public management & $\begin{array}{l}\text { Could be applied in all subfields. For } \\
\text { instance, public policy studies could } \\
\text { address the interactions between } \\
\text { politicians and bureaucrats, and the } \\
\text { impact on policy diffusion }\end{array}$ \\
\hline \multicolumn{5}{|l|}{ Theoretical models } \\
\hline $\begin{array}{l}\text { Proximity models (e.g., } \\
\text { regional diffusion model, } \\
\text { national interaction model, } \\
\text { leader-laggard model) }\end{array}$ & $\begin{array}{l}\text { Various models that look at "proximity" in } \\
\text { different ways; some argue that } \\
\text { geographical distance is important, while } \\
\text { others conceptualize that diffusion and } \\
\text { learning occur among "similar" actors }\end{array}$ & $\begin{array}{c}\text { Berry and Berry } \\
(2014) ; \text { Knill (2005) }\end{array}$ & Public policy & $\begin{array}{l}\text { Could be applied in all subfields. For } \\
\text { instance, public management studies } \\
\text { could study the impact of the behaviour } \\
\text { of proximate organizations }\end{array}$ \\
\hline
\end{tabular}




\begin{tabular}{|l|l|c|c|c|}
\hline Reform paradigms & & & \\
\hline $\begin{array}{l}\text { New public management } \\
\text { (NPM) }\end{array}$ & $\begin{array}{l}\text { A reform paradigm in which private- } \\
\text { sector business management techniques } \\
\text { are introduced into the public sector }\end{array}$ & $\begin{array}{c}\text { Hood (1991); } \\
\text { Osborne and Gaebler } \\
\text { (1992) }\end{array}$ & $\begin{array}{c}\text { Public management } \\
\text { and e-government }\end{array}$ & $\begin{array}{c}\text { Could be applied in all subfields. For } \\
\text { instance, public policy studies could } \\
\text { examine the impact of policies } \\
\text { influenced by NPM }\end{array}$ \\
\hline $\begin{array}{l}\text { New public governance } \\
\text { (NPG) (including notions } \\
\text { such as meta-governance and } \\
\text { collaborative innovation) }\end{array}$ & $\begin{array}{l}\text { A reform paradigm focusing on the } \\
\text { relationship of public organizations with } \\
\text { their external environment and inter- } \\
\text { organizational relationships }\end{array}$ & Osborne (2006) & Public management & $\begin{array}{c}\text { Could be applied in all subfields. For } \\
\text { instance, public policy studies could } \\
\text { examine the impact of inter- } \\
\text { organizational relationships on policy } \\
\text { diffusion }\end{array}$ \\
\hline Neo-Weberian state & $\begin{array}{l}\text { A reform paradigm that defines states as a } \\
\text { territorially demarcated and differentiated } \\
\text { sets of institutions and personnel, each } \\
\text { with a centre that exercises authoritative } \\
\text { rulemaking, backed by the coercive } \\
\text { powers of the state }\end{array}$ & $\begin{array}{c}\text { Pollitt and Bouckaert } \\
(2004)\end{array}$ & Public management & $\begin{array}{c}\text { Could be applied in all subfields. For } \\
\text { instance, public policy studies could } \\
\text { examine the impact of specific } \\
\text { governance traditions on the diffusion of } \\
\text { policies }\end{array}$ \\
\hline
\end{tabular}


Second, the public policy literature is particularly characterized by a well-established range of theoretical models often focusing on proximity aspects. Here, public policy scholars have developed various models that look at "proximity" in different ways. That is, some argue that geographical distance is important, while others conceptualize diffusion and learning as occurring among "similar" actors (i.e., those who suffer similar pressures such as ageing societies, environmental pollution, or economic decline) (e.g., Berry \& Berry, 2014; Knill, 2005).

A final comment here relates to the use of reform paradigms. We found 16 occasions (in the 73 included studies) where reviews referred to reform paradigms rather than to wellestablished theories. This was particularly evident with the reviews rooted in the public management literature. These paradigms include NPM which emphasizes market competition. Further, NPG was also addressed by various authors, including notions such as metagovernance and collaborative innovation, that emphasize multi-actor engagement across organizations (e.g., Sørensen \& Torfing, 2011).

Having now answered our second research question, the next section provides an overview of the main empirical antecedents found in the reviews, and this will enable us to identify those antecedents that are highlighted in the distinct subfields as essential for fostering an innovation's diffusion and adoption, and then consider how they might be integrated.

\section{Main Antecedents in the Diffusion and Adoption Process of Public Sector Innovations}

In this section, we analyse the antecedents of the diffusion and adoption process of public sector innovations as they are identified in the reviews (answering RQ3). As outlined earlier, we address characteristics related to four levels: (1) the environmental level; (2) the organizational level; (3) the innovation itself; and (4) the individual level. 
To identify the extent to which the reviews from the distinct subfields have the same empirical focus, we start by constructing a diagram to highlight the similarities and differences in the main antecedents addressed. Following this, we address in more detail the antecedents found on the distinct levels.

\subsection{Similarities and Differences in Empirical Foci}

Figure 3 highlights the differences in empirical focus regarding the main antecedents stressed in the reviews from the various disciplines. Two main conclusions can be drawn.

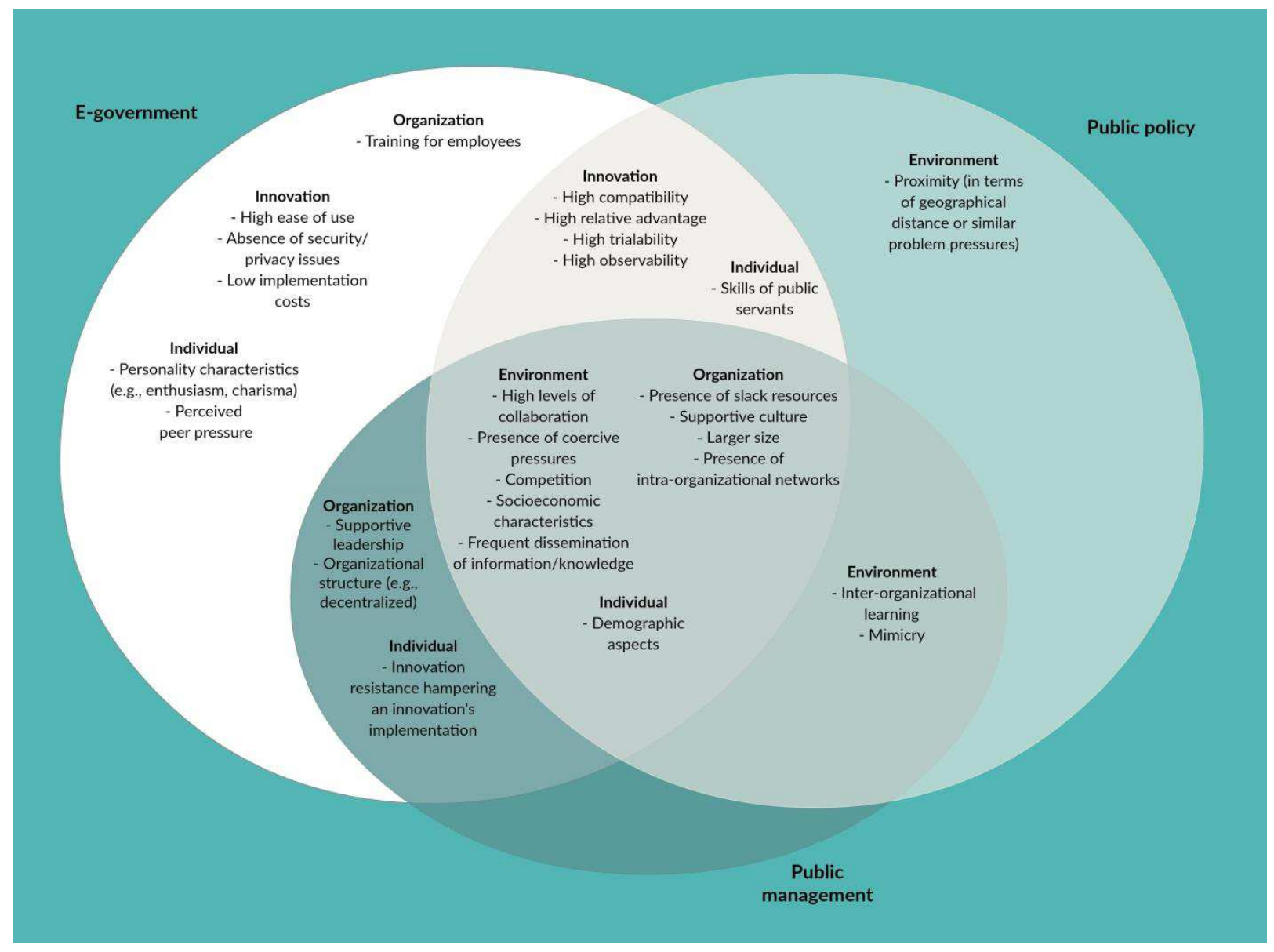

Figure 3. Similarities and Differences in Empirical Foci.

The first conclusion relates to the similarities in the empirical foci of the reviews from the distinct fields. We found that reviews from the various subfields do share important 
similarities, particularly related to the organizational and environmental levels. For instance, the notion of sufficient slack resources, such as money, are often mentioned (e.g., Länsisalmi et al., 2006; Walker, 2014; Zhang et al., 2014). Moreover, scholars often highlight the importance of the participation of relevant stakeholders, such as citizens or civil servants, as a way to successfully foster innovation adoption or diffusion (e.g., Cresswell \& Sheikh, 2013; GilGarcía, 2004).

However, when it comes to the other levels analysed (i.e., innovation and individual), some striking differences can be noted. For instance, we found that only reviews rooted in the e-government literature frequently consider personal characteristics, such as the charisma or enthusiasm of the innovation entrepreneurs involved (e.g., Shea \& Belden, 2016) or perceived peer pressure, such as from colleagues (e.g., Cresswell \& Sheikh, 2013). In identifying such aspects, scholars frequently draw on well-established theories, such as the theory of planned behaviour (Ajzen, 1991), to explain individual innovation acceptance, which is also likely a function of the individual unit of analysis. Moreover, when addressing the innovation level, scholars in this subfield also often note that it is important to consider the costs of implementation as well as an innovation's perceived advantages (e.g., Rana, Dwivedi, \& Williams, 2015; Savoldelli, Codagnone, \& Misuraca, 2014); aspects that are not, or less, highlighted in reviews from the others subfields.

Summarizing, we conclude that, although the distinct subfields share important similarities, there are also significant differences between the various bodies of literature, particularly when it comes to addressing the personality aspects of innovation entrepreneurs, such as their enthusiasm, and the importance of an innovation's attributes, such as its perceived relative advantage (see Rogers 2003).

In the subsections below, we describe in more detail the main antecedents found on the distinct levels. 


\subsection{Environmental Antecedents}

The first category of antecedents that can explain the diffusion and adoption of innovations refers to the environmental level, or the inter-organizational context. Table 3 provides an overview of the main antecedents stressed in the literature (see appendix B for a more detailed overview of the antecedents highlighted in each subfield).

Two main conclusions can be drawn. First, as noted earlier, many reviews from all the subfields highlight the importance of the participation of relevant stakeholders, such as citizens or civil servants, as a way to successfully foster innovation adoption or diffusion (e.g., Cresswell \& Sheikh, 2013; Gil-García, 2004). In doing so, e-government studies particularly note how it is crucial to ensure the involvement of the innovation's end-users during the development of new products and processes, as this could reduce their resistance in the later implementation phase. A good example is provided by Cresswell and Sheikh (2013) who argue how the ongoing involvement of developers and users in the conception and design stages can help ensure that new healthcare systems are likely to be valued and adopted by both professionals and patients.

Alongside the involvement of relevant stakeholders, studies also often refer to the importance of collaborative networks. For instance, Sørensen and Torfing (2011; see also Hartley et al., 2013) argue how multi-actor collaborations, between, for instance, managers, private stakeholders, and users, may facilitate the co-creation of new and promising ideas and forge joint ownership of these ideas such that they may be implemented in practice and produce outcomes that are deemed valuable by the key stakeholders. We also found that the notions of coercion, competition, and mimicry were frequently identified as relevant drivers. Such aspects are particularly highlighted in the public policy literature (e.g., Berry \& Berry, 2014; Jordan \& Huitema, 2014; Knill, 2005), and at times by public management scholars (e.g., Borins, 2014). In this regard, competition is particularly frequently mentioned. For instance, Jordan and Huitema (2014, p. 723) argue that "competitive dynamics are likely to be at work when states 
Table 3. Most Frequently Mentioned Environmental Antecedents (Resulting in an Increase in Innovation Diffusion/Adoption Unless Otherwise Stated)

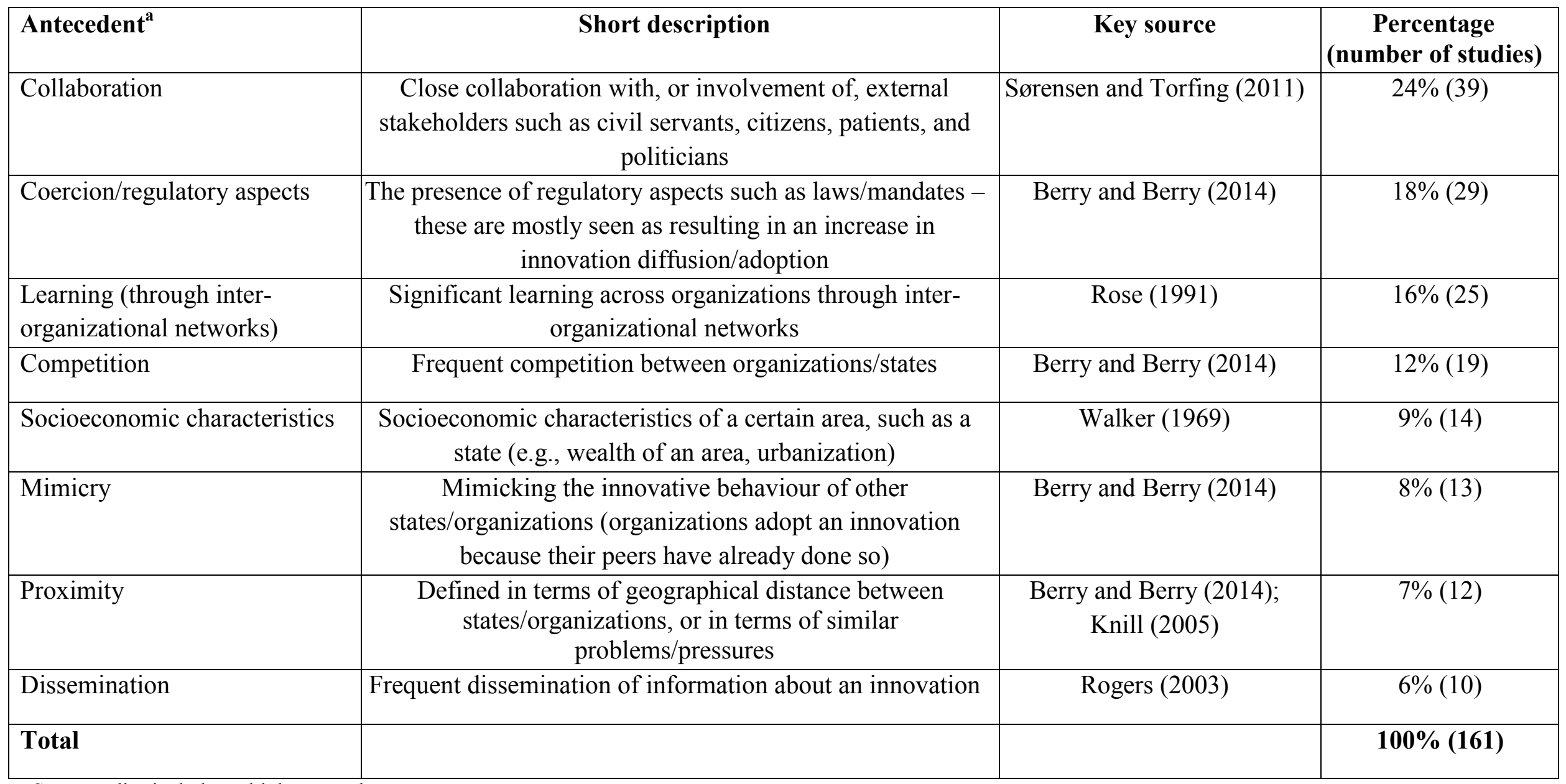

a. Some studies include multiple antecedents. 
adjust their policies to attract inward investment or avoid becoming a 'welfare magnet'. These 'race to the top' and 'race to the bottom' dynamics are a prominent theme in many of the studies of policy convergence $[\ldots] "$.

\subsection{Organizational Antecedents}

The second category of antecedents that may explain the diffusion and adoption of an innovation relates to the structural and cultural features of an organization (see table 4).

The first conclusion that can be drawn is that the notion of requiring sufficient slack resources for successful innovation take up is frequently found across all three literature streams (e.g., Länsisalmi et al., 2006; Walker, 2014; Zhang et al., 2014). 'Slack' refers to the availability of organizational resources, such as money, staff, and ICT facilities, and is often seen as essential for successful innovation implementation. For instance, during the adoption and implementation of an innovation, organizations need to assign staff and resources to manage what can be a difficult time. In such circumstances, slack resources may provide organizations with the ability to innovate, to bear the costs of innovation, and to experiment (e.g., Walker, 2014).

Alongside the role of slack resources, reviews from all the subfields also frequently emphasize the role of leadership as another crucial element in ensuring an innovation's when addressing effective leadership strategies that could be employed, Wallis and Goldfinch (2013) argue how effective leadership relates to a process that stimulates waves of enthusiasm that drive the process of cultural changes widely across and within public organizations. According to Wallis and Goldfinch (2013, p. 26), this 'strategic change vision' process implicitly seeks to exclude and marginalize sceptical voices from the decision-making process by treating them as expressions of resistance to change, which need to be overcome. Similarly, other managerial strategies which have been put forward refer to involving leaders in testing a 
Table 4. Most Frequently Mentioned Organizational Antecedents (Resulting in an Increase in Innovation Diffusion/Adoption Unless Otherwise Stated)

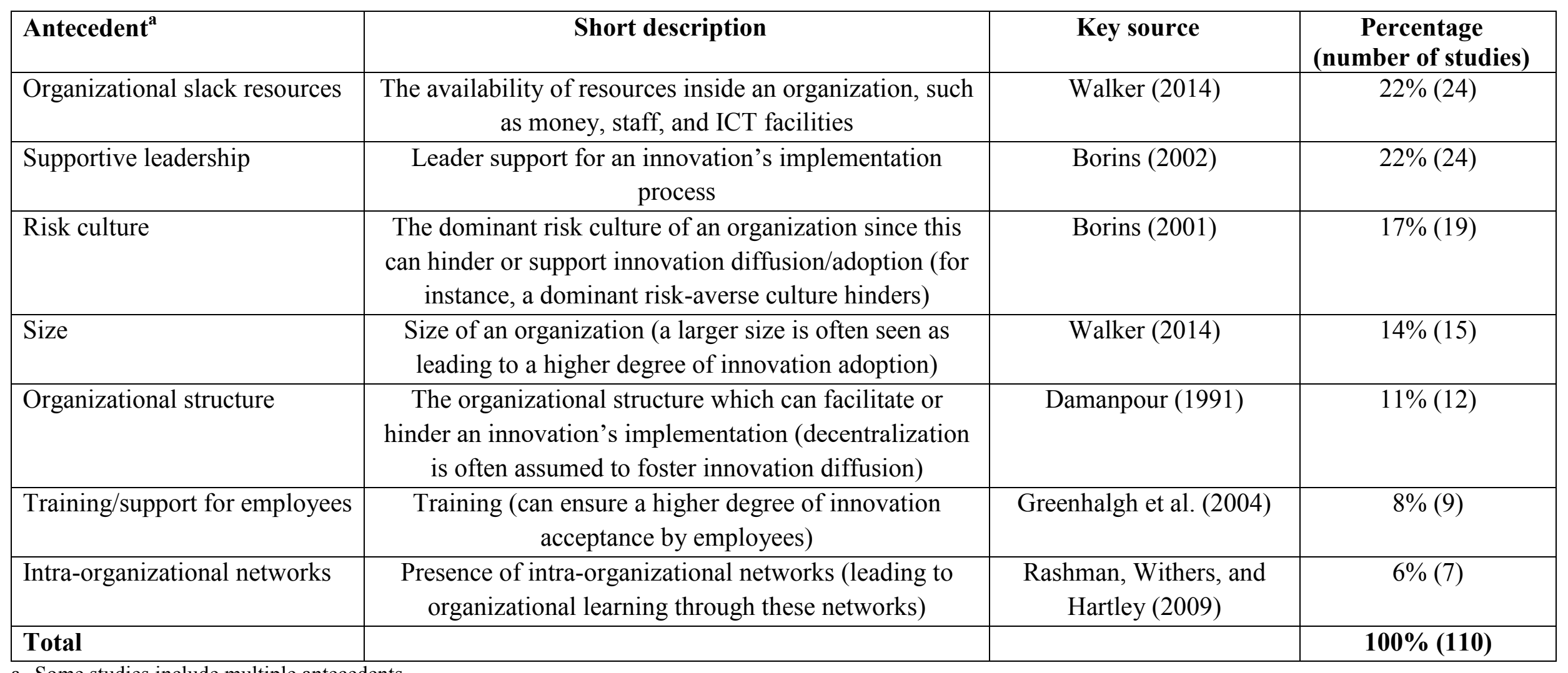

a. Some studies include multiple antecedents. 
particular innovation, such as a technology system, and taking on the role of experts and 'super-users' when it is introduced (e.g., Gagnon et al., 2012).

\subsection{Innovation Antecedents}

The third category we address is innovation-level antecedents that could promote or hinder an innovation's diffusion and adoption (see table 5).

The first conclusion here is that the innovation attributes identified by Rogers (2003) are often found, but rarely in the public management literature. Rogers noted that five perceived attributes of an innovation (relative advantage, compatibility, complexity (defined as ease of use in TAM), trialability, and observability) increase the rate of adoption of an innovation. Of these attributes, compatibility and ease of use were frequently mentioned in the reviews (e.g., Rana et al., 2015).

Another important finding is that these five attributes are not all embracing: an innovation has other important attributes that can stimulate the take-up of an innovation in the public sector. Such aspects are particularly highlighted in the e-government literature. They include straightforward attributes such as the cost of an innovation (e.g. Gagnon et al., 2012). However, various scholars also note that it is important to consider security and privacy issues (e.g., Savoldelli et al., 2014). This is particularly relevant when, for instance, developing governmental websites or e-health applications that involve patient information. E-health applications that include patient information are often viewed with suspicion and seen as having a high risk, for instance that hacking could result in patient information becoming available to the general public. 
Table 5. Most Frequently Mentioned Innovation Antecedents (Resulting in an Increase in Innovation Diffusion and Adoption Unless Otherwise Stated)

\begin{tabular}{|c|c|c|c|}
\hline Antecedent $^{\mathrm{a}}$ & Short description & Key source & $\begin{array}{c}\text { Percentage } \\
\text { (number of studies) }\end{array}$ \\
\hline Ease of use & $\begin{array}{l}\text { The degree to which an innovation is perceived as easy to } \\
\text { understand and user friendly }\end{array}$ & $\begin{array}{l}\text { Davis (1989); } \\
\text { Rogers (2003) }\end{array}$ & $27 \%(23)$ \\
\hline Compatibility & $\begin{array}{c}\text { The extent to which the innovation is in line with existing ways } \\
\text { of working in the organization }\end{array}$ & Rogers (2003) & $23 \%(20)$ \\
\hline $\begin{array}{l}\text { Relative advantage/perceived } \\
\text { usefulness }\end{array}$ & $\begin{array}{l}\text { The perceived usefulness and benefits of an innovation relative } \\
\text { to current tools or procedures }\end{array}$ & $\begin{array}{l}\text { Davis (1989); } \\
\text { Rogers (2003) }\end{array}$ & $15 \%(13)$ \\
\hline $\begin{array}{l}\text { Security and privacy issues } \\
\text { (negative) }\end{array}$ & $\begin{array}{c}\text { Concerns about security and privacy issues related to the use of } \\
\text { governmental websites or other electronic applications, with } \\
\text { perceptions of a lack of security and privacy resulting in a } \\
\text { decrease in innovation diffusion/adoption }\end{array}$ & $\begin{array}{l}\text { Savoldelli, Codagnone, } \\
\text { and Misuraca (2014) }\end{array}$ & $10 \%(9)$ \\
\hline Costs (negative) & $\begin{array}{c}\text { Costs of an innovation's implementation, with high costs } \\
\text { decreasing an innovation's diffusion/adoption }\end{array}$ & Greenhalgh et al. (2004) & $9 \%(8)$ \\
\hline Trialability & Possibility to experiment (e.g., use of pilot projects) & Rogers (2003) & $9 \%(8)$ \\
\hline Observability & $\begin{array}{c}\text { The extent to which others (such as other organizations) can see } \\
\text { the innovation being used }\end{array}$ & Rogers (2003) & $7 \%(6)$ \\
\hline Total & & & $100 \%(87)$ \\
\hline
\end{tabular}

b. Some studies include multiple antecedents. 


\subsection{Individual Antecedents}

Our final category of antecedents that can explain innovation diffusion and adoption refers to the individual level and addresses personal characteristics of the individuals involved in diffusion and adoption processes (see table 6).

Two main conclusions can be drawn. First, we found that many reviews, particularly those from the public management and e-government fields, highlight individual attitudes towards an innovation's implementation, mostly framed in terms of resistance to change, with more resistance resulting in less adoption (e.g., Savoldelli et al., 2014). When it comes to other relevant antecedents (alongside the most frequently mentioned antecedents of attitude towards an innovation and skills), we found that these are almost exclusively addressed by egovernment scholars.

The second main conclusion relates to the theories that the analysed reviews draw upon. Particularly e-government scholars often draw on well-established theories, such as the theories of reasoned action and planned behaviour (e.g., Rana et al,. 2015; Titah \& Barki, 2006). Such theories posit that the intention to adopt and use an innovation will be higher when important others (such as colleagues and family) evaluate an innovation positively (i.e., satisfying a subjective norm, see Ajzen, 1991; Fishbein \& Ajzen, 1975). For instance, Cresswell and Sheikh (2013) highlight how the perceptions of healthcare professionals concerning the potential adoption of new healthcare technologies are influenced by the judgments of colleagues and patients, with positive perceptions by such peers resulting in a higher rate of innovation adoption. 
Table 6. Most Frequently Mentioned Individual Antecedents (Resulting in an Increase in Innovation Diffusion/Adoption Unless Otherwise Stated)

\begin{tabular}{|c|c|c|c|}
\hline Antecedent $^{\mathrm{a}}$ & Short description & Key source & $\begin{array}{c}\text { Percentage } \\
\text { (number of studies) }\end{array}$ \\
\hline Skills (often ICT-related) & Necessary individual skills, often ICT-related & Greenhalgh et al. (2004) & $29 \%(16)$ \\
\hline Personality characteristics & $\begin{array}{l}\text { Personality (e.g., autonomy, enthusiasm, charisma) } \\
\text { of the individuals involved in an innovation's } \\
\text { implementation process, which can positively or } \\
\text { negatively influence innovation diffusion/adoption }\end{array}$ & Shea and Belden (2016) & $16 \%(9)$ \\
\hline Perceived peer pressure & $\begin{array}{l}\text { An individual's perceptions of a particular } \\
\text { innovation, which is influenced by the judgment of } \\
\text { significant others (e.g., family, friends, and } \\
\text { professionals), with positive perceptions resulting in } \\
\text { an increase in innovation diffusion/adoption }\end{array}$ & $\begin{array}{l}\text { Ajzen (1991); Fishbein } \\
\text { and Ajzen (1975) }\end{array}$ & $13 \%(7)$ \\
\hline Total & & & $100 \%(55)$ \\
\hline
\end{tabular}

a. Some studies include multiple antecedents. 


\section{Conclusion}

The goal of this article has been to synthesize research findings from the public management, public policy, and e-government literature streams on innovation diffusion and adoption in the public sector. We conducted a meta-synthesis because such reviews have "great potential for providing 'big picture' summaries of empirical research" (Cooper \& Koenka, 2012, p. 459). In so doing, the main aim of the article was to see how the different subfields that study public sector innovation diffusion and adoption can learn from, and use, each other's insights.

We first analysed the most commonly cited publications in the three scholarly subfields (public management, public policy, and e-government) that address public sector innovation diffusion and adoption. The results of our network analysis of 1,420 studies showed that only one work, namely Rogers' innovation theory (1983, 1995 and 2003 editions), is widely referred to by studies in all three subfields, while DiMaggio and Powell (1983) is also mentioned in all the subfields, albeit only on a few occasions.

Second, we examined the theories, theoretical models, and reform paradigms used in the reviews from the three subfields in order to see whether the fields' assumptions and approaches overlap and how they can learn from each other. Apart from drawing on Rogers, we found that reviews from the distinct subfields tend to draw on their own theories, all of which have their own strengths and weaknesses. For instance, public management and public policy scholars often focus on the macro-institutional environment of public organizations, for instance by referring to reform movements such as NPM (Hood, 1991; Osborne \& Gaebler, 1992). However, aspects of an individual that are also relevant in the innovation diffusion and adoption process (such as attitude towards an innovation) were almost exclusively addressed by e-government scholars, reflected in, for instance, their uses of the social psychology theory of planned behaviour (Ajzen, 1991), reasoned action (Fishbein \& Ajzen, 1975), and technology acceptance models such as UTAUT (Venkatesh et al.m 2003). The advantage of adopting a macro-institutional approach is that it places adoption and diffusion in a broader perspective, 
and particularly emphasizes reasons for adoption and diffusion related to the environment that public organizations are part of. However, the role of individual actors is often ignored in such approaches, despite their roles being emphasised in the other theories mentioned. Hence, we conclude that, given that all theories have their own strengths and weaknesses, such distinct theoretical approaches should be ideally combined in future research.

Third, we looked into the main antecedents that drive the diffusion and adoption of public sector innovation. Here, we found that the distinct subfields share important similarities, such as the focus on stakeholder participation and the availability of organizational slack resources. One particularly striking finding was that scholars from all subfields often highlight the importance of the participation of relevant external and internal stakeholders, such as citizens or civil servants, as a way to successfully foster innovation adoption or diffusion activities. This also aligns with recent notions such as that of collaborative governance (Torfing, 2016) and the open innovation concept (Chesbrough, 2003), with the latter particularly focusing on the involvement of end-users. However, and related to our previous remark regarding the theories used, our analysis has also highlighted how reviews from the distinct subfields frequently focus on their own sets of antecedents. For instance, individual aspects, such as perceived peer pressure, were scarcely addressed outside the e-government literature.

A final observation in the context of our empirical findings relates to the concepts examined. We found that studies often fail to make it clear whether they are addressing diffusion or adoption, or indeed even see these as distinct processes. The relationship between the diffusion and adoption stages, and the interdependencies between them, were often ignored. Rogers (2003) notes how adoption is the result of a diffusion process, in that people or organizations, as part of a social system, may adopt a new idea, behaviour, or product once it has been diffused. Hence, it seems likely that the diffusion process affects adoption. Further, the widespread adoption of an innovation can create a new diffusion process. However, our 
analysis shows that such interdependencies have been largely ignored, and we would stress the need for a more elaborate examination of this topic in future studies.

When reflecting on the conclusions of this study, we again acknowledge that metasyntheses are limited in that the most recent publications are likely to have been overlooked while studies that date back several years or even decades might be included in the review studies (Cooper \& Koenka, 2012). Hence, one should view our meta-synthesis as an investigation into the overall state-of-the-art of this topic, and as a thematic analysis to identify key uncertainties that warrant further exploration.

\section{Future Research Agenda}

Having completed this meta-synthesis, what do our findings tell us about the current status of public sector innovation diffusion and adoption, and where should research go from here? Based on the results of this meta-synthesis, we now outline several potential avenues for future research.

A first suggestion relates to the different theories and approaches that we have seen used in the reviewed studies. As already noted, we found from the reviews that the distinct subfields tend to draw on their own theories, which also relates to the observation that public management scholars often neglect individual-level issues. Further, well-known theories such as neo-institutionalism were rarely applied. Following this finding, and dependent on the specific research questions to be addressed, two avenues for future research can be put forward. First, when studying innovation diffusion and adoption, one avenue would be to use a microlevel approach when drawing on meso- or macro-level paradigms such as neo-institutionalism. In this way, new insights might be gained through innovative research that applies micro-level theories to phenomena usually examined on the meso- or macro-levels. For instance, when drawing on neo-institutional theory to explain innovation diffusion and adoption, scholars could focus more on neo-institutionalism's micro-foundations, and indeed institutional theory 
has historically called for more explicit attention to this (e.g., Powell \& Colyvas, 2008). Here, Felin et al. (2012) argue that individual-level aspects, such as the skills and abilities of employees, are important for understanding collective phenomena such as specific organizational routines. It follows that theoretical and empirical work that encompasses multilevel effects might be needed to advance the understanding of innovation diffusion and adoption. This may require the combination of different theories, such as neo-institutional theory (DiMaggio \& Powell, 1983) with behavioural theories (Ajzen, 1991; Fishbein \& Ajzen, 1975), that address different levels of analysis. For instance, research could address the relationship between lower-level phenomena, such as employee attitudes and behavioural intentions to use an innovation (Ajzen, 1991; Fishbein \& Ajzen, 1975), and outcomes such as the adoption of a new policy by an organization and its subsequent spread across organizations within a particular field. Our meta-synthesis has shown that such combinations of different theoretical strands remain largely absent.

A second suggestion relates to the importance of stakeholder and end-user participation in the innovation diffusion and adoption process, an aspect that was quite strongly highlighted in the analysed reviews. In this regard, the private sector concept of open innovation (Chesbrough, 2003) could offer useful insights as this concept particularly focuses on inviting problem-solvers to help reinvent products and services that might contribute to the survival of the organization. For instance, what would be the impact of living labs, in which citizens are involved, in supporting public open innovation processes? Moreover, we also see value in future research examining collaborative innovation approaches in greater detail, for instance by examining the interplay between political leadership and collaborative innovation (Torfing \& Ansell, 2017) as this particularly relates to the legitimacy of public sector innovation adoption practices.

A third suggestion relates to the relationship between the diffusion and adoption stages, and the interdependencies between them, as these issues were poorly addressed. Here, future 
studies could draw more extensively on the distinctions outlined by Rogers (2003), including the various types of adopters and the distinct steps in the innovation adoption process, namely knowledge, persuasion, decision, implementation, and confirmation. Further, future studies could also use the definitions of diffusion and adoption outlined by Rogers to make clear what they are studying.

Finally, we found that many important aspects, such as proximity between actors in terms of similar problems or geographical distance, were only briefly addressed in the review studies we analysed. As such, future studies could usefully address these aspects in more detail.

In conclusion, the goal of this article was to compare and integrate the main research findings on the diffusion and adoption of public sector innovations by summarizing two decades of research on this topic. The findings from our analysis demonstrate how the current overlapping interests and the diverging approaches could be integrated to produce future research that is theoretically robust and practically useful. We hope that other researchers will adopt such an integrative perspective in future studies and, through this, advance knowledge on innovation diffusion and adoption in the public sector.

\section{Acknowledgements}

In order to conduct the meta-synthesis of the literature, we consulted a number of experts to help us find eligible review studies. We thank these experts, specifically Prof. Greta Nasi from Bocconi University and Prof. Trisha Greenhalgh from the University of Oxford. We would furthermore like to thank the three anonymous referees who offered valuable critiques and provided us with constructive suggestions, thereby improving the article substantially. Our gratitude also goes to Judith Gulpers for her excellent assistance with the network analyses. Lars Tummers acknowledges funding of NWO grant VENI-451-14-004. 


\section{Funding}

This work was supported by the European Union Seventh Framework Programme (Project Learning from Innovation in Public Sector Environments, LIPSE, 320090). The project focuses on studying social innovations in the public sector (www.lipse.org).

\section{References}

Ajzen, Icek. 1991. The theory of planned behavior. Organizational Behavior and Human Decision Processes 50:179-211.

American Association for the Advancement of Science. 2016. http://www.aaas.org. Accessed October 4, 2016.

Bekkers, Victor. 2007. Modernization, public innovation and information and communication technologies: The emperor's new clothes? Information Polity 12:103-07.

Bekkers, Victor, Jurian Edelenbos, and Bram Steijn. 2011. Innovation in the public sector. Linking capacity and leadership. New York, NY: Palgrave Macmillan.

Berry, Frances Stokes, and William D. Berry. 1990. State lottery adoptions as policy innovations: An event history analysis. American Political Science Review 84:395-415.

Berry, Frances Stokes, and William D. Berry. 2014. Innovation and diffusion models in policy research. In Theories of the policy process, $3^{\text {rd }}$ edn, eds. Paul A. Sabatier and Christopher M. Weible, 307-62. Boulder, CO: Westview Press.

Borins, Sandford. 2001. Encouraging innovation in the public sector. Journal of Intellectual Capital 2:310-19.

Borins, Sandford. 2002. Leadership and innovation in the public sector. Leadership \& Organization Development Journal 23:467-76.

Borins, Sandford. 2014. Emergence and diversity: Public sector innovation research. In The persistence of innovation in government, 11-39. Washington, DC: Brookings Institution Press. 
Buchanan, James M., and Robert D. Tollison. 1984. The theory of public choice - II. Ann Arbor, MI: The University of Michigan Press.

Chesbrough, Henry W. 2003. Open innovation: The new imperative for creating and profiting from technology. Boston, MA: Harvard Business School Press.

Cooper, Harris, and Alison C. Koenka. 2012. The overview of reviews: Unique challenges and opportunities when research syntheses are the principal elements of new integrative scholarship. American Psychologist 67:446-62.

Cresswell, Kathrin, and Aziz Sheikh. 2013. Organizational issues in the implementation and adoption of health information technology innovations: An interpretative review. International Journal of Medical Informatics 82:e73-e86.

Damanpour, Fariborz. 1991. Organizational innovation: A meta-analysis of effects of determinants and moderators. Academy of Management Journal 34:555-90.

Davis, Fred D. 1989. Perceived usefulness, perceived ease of use, and user acceptance of information technology. MIS Quarterly 13:319-40.

Davis, Fred D., Richard P. Bagozzi, and Paul R. Warshaw. 1989. User acceptance of computer technology: A comparison of two theoretical models. Management Science 35:982-1003.

De Vries, Hanna, Victor Bekkers, and Lars Tummers. 2016. Innovation in the public sector: A systematic review and future research agenda. Public Administration 94:144-66.

DiMaggio, Paul J., and Walter W. Powell. 1983. The iron cage revisited: Collective rationality and institutional isomorphism in organizational fields. American Sociological Review 48: $147-60$.

Dolowitz, David P., and Davis Marsh. 1996. Who learns what from whom: A review of the policy transfer literature. Political Studies 44:343-57.

Felin, Teppo, Nicolai J. Foss, Koen H. Heimeriks, and Tammy L. Madsen. 2012. Microfoundations of routines and capabilities: Individuals, processes, and structure. Journal of Management Studies 49:1351-74. 
Fishbein, Martin, and Icek Ajzen. 1975. Belief, attitude, intention and behavior: An introduction to theory and research. Reading, MA: Addison-Wesley.

Flynn, Norman. 2007. Public sector management. Thousand Oaks, CA: Sage.

Gagnon, Marie-Pierre, Marie Desmartis, Michel Labrecque, Josip Car, Claudia Pagliari, Pierre Pluye, Pierre Frémont, Johanne Gagnon, Nadine Tremblay, and France Légaré. 2012. Systematic review of factors influencing the adoption of information and communication technologies by healthcare professionals. Journal of Medical Systems 36:241-77.

Gil-García, J. Ramón. 2004. Information technology policies and standards: A comparative review of the states. Journal of Government Information 30:548-60.

Gil-García, J. Ramón, Sharon S. Dawes, and Theresa A. Pardo. 2017. Digital government and public management research: Finding the crossroads. Public Management Review:1-14. Gopalakrishnan, Shanti, and Fariborz Damanpour. 1997. A review of innovation research in economics, sociology and technology management. Omega 25:15-28.

Gray, Virginia. 1973. Innovation in the states: A diffusion study. American Political Science Review 67:1174-85.

Greenhalgh, Trisha, Glenn Robert, Fraser Macfarlane, Paul Bate, and Olivia Kyriakidou. 2004. Diffusion of innovations in service organizations: Systematic review and recommendations. Milbank Quarterly 82:581-629.

Hartley, Jean. 2005. Innovation in governance and public services: Past and present. Public Money \& Management 25:27-34.

-2016. Organizational and governance aspects of diffusing public innovation. In Enhancing public innovation by transforming public governance, eds. Jacob Torfing and Peter Triantafillou, 95-114. Cambridge: Cambridge University Press.

Hartley, Jean, Eva Sørensen, and Jacob Torfing. 2013. Collaborative innovation: A viable alternative to market competition and organizational entrepreneurship. Public Administration Review 73:821-30. 
Hood, Christoper. 1991. A public management for all seasons? Public Administration 69:3-19.

Jordan, Andrew, and Dave Huitema. 2014. Innovations in climate policy: The politics of invention, diffusion, and evaluation. Environmental Politics 23:715-34.

Knill, Christoph. 2005. Introduction: Cross-national policy convergence: concepts, approaches and explanatory factors. Journal of European Public Policy 12:764-74.

Lane, Peter J., Balaji R. Koka, and Seemantini Pathak. 2006. The reification of absorptive capacity: A critical review and rejuvenation of the construct. The Academy of Management Review 31:833-63.

Länsisalmi, Hannakaisa, Mika Kivimäki, Pirjo Aalto, and Raija Ruoranen. 2006. Innovation in healthcare: A systematic review of recent research. Nursing Science Quarterly 19:66-72.

Liberati, Alessandro, Douglas G. Altman, Jennifer Tetzlaff, Cynthia Mulrow, Peter C.

Gøtzsche, John P. A. Ioannidis, Mike Clarke, P. J. Devereaux, Jos Kleijnen, and David Moher. 2009. PRISMA statement for reporting systematic reviews and meta-analyses of studies that evaluate health care interventions: Explanation and elaboration. PloS Medicine 151:e1000100.

Meijer, Albert. 2015. E-governance innovation: Barriers and strategies. Government Information Quarterly 32:198-206.

Moore, Gary C., and Izak Benbasat. 1991. Development of an instrument to measure the perceptions of adopting an information technology innovation. Information Systems Research 2:192-222.

Mulgan, Geoff, and David Albury. 2003. Innovation in the public sector. London: Strategy Unit Cabinet Office.

Osborne, David E., and Ted Gaebler. 1992. Reinventing government: How the entrepreneurial spirit is transforming government. Reading, MA: Addison-Wesley.

Osborne, Stephan. P. 2006. The new public governance? Public Management Review 8:37787. 
Osborne, Stephen P., and Louise Brown. 2011. Innovation, public policy and public services delivery in the UK: The word that would be king? Public Administration 89:1335-50.

Pollitt, Christopher, and Geert Bouckaert. 2004. Public management reform: A comparative analysis, $2^{\text {nd }}$ edn. Oxford: Oxford University Press.

Powell, Walter W., and Jeannette A. Colyvas. 2008. Microfoundations of institutional theory. In Sage handbook of organizational institutionalism, eds. Royston Greenwood, Christine Oliver, Kerstin Sahlin, and Roy Suddaby, 276-98. Thousand Oaks, CA: Sage.

Rana, Nripendra P., Yogesh K. Dwivedi, and Michael D. Williams. 2015. A meta-analysis of existing research on citizen adoption of e-government. Information Systems Frontiers 17: $547-63$.

Rashman, Lyndsay, Erin Withers, and Jean Hartly. 2009. Organizational learning and knowledge in public service organizations: A systematic review of the literature. International Journal of Management Reviews 11:463-94.

Rogers, Everett M. eds. 1983/1995/2003. Diffusion of innovations. New York: Free Press.

Rose, Richard. 1991. What is lesson-drawing? Journal of Public Policy 11:3-30.

Savoldelli, Alberto, Cristiano Codagnone, and Gianluca Misuraca. 2014. Understanding the egovernment paradox: Learning from literature and practice on barriers to adoption. Government Information Quarterly 31:63-71.

Shea, Christopher Michael, and Charles M. Belden. 2016. What is the extent of research on the characteristics, behaviors, and impacts of health information technology champions? A scoping review. BMC Medical Informatics and Decision Making 16:1-17.

Shipan, Charles R., and Craig Volden. 2012. Public policy: Seven lessons for scholars and practitioners. Public Administration Review 72:788-96.

Sørensen, Eva, and Jacob Torfing. 2011. Enhancing collaborative innovation in the public sector. Administration \& Society 43:842-68. 
Taylor, John A., and Miriam Lips. 2008. The citizen in the information polity: Exposing the limits of the e-government paradigm. Information Polity 13:139-52.

Taylor, Shirley, and Peter A. Todd. 1995. Understanding information technology usage: A test of competing models. Information Systems Research 6:144-76.

Titah, Ryad, and Henri Barki. 2006. E-government adoption and acceptance: A literature review. International Journal of Electronic Government Research (IJEGR) 2:23-57.

Torfing, Jacob. 2016. Collaborative innovation in the public sector. Washington, DC: Georgetown University Press.

Torfing, Jacob, and Christopher Ansell. 2017. Strengthening political leadership and policy innovation through the expansion of collaborative forms of governance. Public Management Review 19:37-54.

Tornatzky, Louis G., and Katherine J. Klein. 1982. Innovation characteristics and innovation adoption-implementation: A meta-analysis of findings. IEEE Transactions on Engineering Management 1:28-45.

Venkatesh, Viswanath, and Fred D. Davis. 2000. A theoretical extension of the technology acceptance model: Four longitudinal field studies. Management Science 46:186-204.

Venkatesh, Viswanath, Michael G. Morris, Gordon B. Davis, and Fred D. Davis. 2003. User acceptance of information technology: Toward a unified view. MIS Quarterly 27:425-78.

Walker, Jack L. 1969. The diffusion of innovations among the American states. American Political Science Review 63:880-99.

Walker, Richard M. 2014. Internal and external antecedents of process innovation: A review and extension. Public Management Review 16:21-44.

Wallis, Joe, and Shaun Goldfinch. 2013. Explaining patters of public management reform diffusion. In Handbook of innovation in public services, eds. Stephen P. Osborne and Louise Brown, 15-28. Cheltenham: Edward Elgar. 
Zaltman, Gerald, Robert Duncan, and Jonny Holbek. 1973. Innovations and organizations. New York, NY: John Wiley \& Sons.

Zhang, Hui, Xiaolin Xu, and Jianying Xiao. 2014. Diffusion of e-government: A literature review and directions for future directions. Government Information Quarterly 31:63-90. 